\title{
Optimization of the Use of Information Technology in Learning Administration at SDN Hurip Jaya 03
}

\author{
Rakhmat Purnomo a), Wowon Priatna, and Ajif Yunizar Pratama Yusuf \\ Program Studi S1 Informatika, Universitas Bhayangkara Jakarta Raya, Bekasi, Indonesia \\ a)Corresponding Author: rakhmat.purnomo@dsn.ubharajaya.ac.id
}

\begin{abstract}
Information Technology have to be an enabler of every activity. With the information technology, the effectiveness and efficiency of work shoultd be increase. The obstacles faced, with the existence of information technology, can be an alternative solution. SDN Hurip Jaya 03 Babelan is a school located on the north coast of Bekasi Regency. This school has a challenge where cable internet access from Provider has not yet entered so that educators and education staff, students use independent resources for internet access. Administrative and learning activities already use computers but have not utilized cloud applications such as google forms, google classroom, and shorter url applications for learning e-learning. The educators and education staff are also still working with computers in typing so that their work is less effective. The solution we provide is to share knowledge, knowledge, experience and resources in providing solutions to existing problems. The activities that have been carried out are providing wifi modem and usb wifi resources for internet access, training in fast typing the 10 finger method, using google forms and google classroom for administration and learning, as well as the bit.ly application for naming links to make reading easier. We hope that if the material presented can be trained and applied seriously, it will certainly be useful in supporting administrative and learning activities.
\end{abstract}

Keywords: Fast typing, Google Classroom, Google Form, Wisdom Surfing

\section{INTRODUCTION}

Optimization is an activity to find the best way that can be done to achieve maximum results by empowering existing resources (Ramadhani \& Arifin, 2013). Optimization is carried out in all fields, be it business, economics, culture, technology, science, and education. Optimization is carried out, among others, for; (1) Troubleshooting, (2) Decision Making, and (3) Saving resources. By doing optimization, organizational goals can be achieved effectively and efficiently.

Information technology is a tool that already exists and can be used by anyone to enable or enable all fields. Information technology is expected to solve problems, simplify and speed up decision making, and maximize the potential of organizational resources. The existence of information technology, its function must be maximized, especially the current conditions where the Corona Virus 19 pandemic is still engulfing the Republic of Indonesia.

Many innovations were made to maximize the role of information technology to optimize sales, including those made by (Zulfahmi et al., 2020) regarding e-commerce. The service activities carried out succeeded in changing the mindset of students to sell using internet media so that the market scope was wider. The same program was carried out by (Ramadhani \& Arifin, 2013) who used e-commerce to market the products of micro, small and medium enterprises (MSMEs).

In the field of education, especially administration and teaching and learning process, technology is very helpful in strengthening the role of educators. A study conducted by (Adisel \& Prananosa, 2020) on information technology concluded that the infrastructure to support the use of information technology was not evenly distributed and human resources were not yet ready to utilize it. This is a challenge for all parties who will optimize information technology in the field of education. This challenge was reviewed by (Aisa \& Lisvita, 2020) which requires the learning process to be carried out even at home. The results of the study show that students are able to respond to material quickly if it is delivered using information technology devices.

Learning that uses information technology is also carried out at the elementary school level (Astini, 2020), high school level (Manullang et al., 2021), even at universities (Romadani \& 
Prasetyo, 2020). Information technology is also used to assess performance (Priatna \& Purnono, 2020; Purnomo \& Putra, 2020). In the government sector also to assess performance using the google form (Kasmawati, 2020). In the field of community empowerment, information technology is also used to improve the nature of mutual cooperation to build villages (Muafani, 2021). These examples show that many fields have used information technology to optimize the potential of resources.

Sekolah Dasar Negeri Hurip Jaya 03 Public (Elementary School) is located in Kp. Pondok Dua RT. 008 RW. 004, Hurip Jaya Village, Babelan District, Bekasi Regency who need assistance in empowering educators and education staff for administrative and learning processes. Based on the results of interviews with school principals and observations in the school environment, there are problems that will be resolved through community service activities, namely (1) Difficulty accessing the Internet and their knowledge, (2) the slow work of teachers and staff in using computers, and (3) not knowing the use of computers. google classroom, google forms, and shorter Uniform Resource Locator (URL) applications. It is hoped that if participants train seriously the material presented and do the exercises, participants can master the competencies set and solve existing problems.

\section{METHOD}

This community service is carried out offline by coming directly to SDN Hurip Jaya 03. The location is in Kp. Pondok Dua RT. 008 RW. 004, Hurip Jaya Village, Babelan District, Bekasi Regency. The activity will be held on Thursday, July 29, 2021, starting from 09.00 to 15.00 WIB. The training participants are the entire population of 14 participants.

This series of community service activities includes (1) Survey and Observation, where interviews are conducted with principals and teachers, teachers, and staff. Observation aims to see firsthand the situation and conditions, (2) Preparation of training / workshops, From the results of the survey and observations we design the required materials, (3) Implementation, is the day the training is carried out, (4) Follow-up, is control over the results obtained. achieved after training.

\section{RESULTS}

The results at the survey and observation stages are in the form of partner data. We know the needs and problems of partners. We also know the distance, travel conditions, partner community environment, and things needed for service activities. The Training Preparation stage produces materials to be presented and purchases the necessary tools and materials. The implementation stage resulted in this activity being the training carried out, explaining the material, demonstrating the application, and direct practice by the participants. The follow-up stage produces completed exercises and feedback.

\section{DISCUSSION}

The discussion of the results of the service is divided into four parts, namely;

1. Survey and Observation

We conducted a survey at SDN Hurip Jaya 03 as well as observed on Wednesday, June 23, 2021. The results of the observations revealed information about what needs were needed to prepare for training or workshops. We looked at the physical condition of the school, rooms, learning facilities, computers, internet access, places of worship, information on the mading, organizational structure boards, school vision and mission boards, and others. We also obtained information through interviews with the principal and teachers. The results of this survey found that it is rare from Campus 2 Bekasi, Bhayangkara University, Greater Jakarta to SDN Hurip Jaya 03 Babelan as far as $\pm 27 \mathrm{Km}$ which is taken for \pm 1 hour by motor vehicle. While the results of the observations revealed that the main problems that we will focus on for the training include (1) Procurement of WiFi Modems and USB WiFi, (2) sharing knowledge about Wisely Using the Internet, (3) Typing fast with the 10 Finger method, and (4) Using Google Form (Kasmawati, 2020), 
Google Classroom (Manullang et al., 2021), and Shorter URL Application (Uniform Resource Locator) with bit.ly.

2. Training Preparation

Thursday, July 22, 2021 we purchased training needs in the form of a WiFi Modem and USB $\mathrm{WiFi}$. We test the functionality of the tool so that it is ready for use on the day of implementation. We inform the training class by providing a google classroom link. Trainees join this class for training administration needs. All materials, pre-test and post-test, attendance, assignments, and evaluation of training will be well documented in google classroom.

3. Implementation

The training/workshop will be held on Thursday, July 29, 2021, from 09.00 to 15.00 WIB. Event activities are carried out offline while maintaining strict health protocols. The decision to implement offline training has been agreed by all parties, especially the principal with the school supervisor and teachers. Offline training is desired so that the results of the training can be maximized. Prior to the implementation of the training, a pre-test was given first and after the training was given a post-test. Table 1 is a breakdown of activities along with their time and contents.

4. Follow-up

We will follow up the workshop/training on Thursday, 29 July 2021 by asking questions in Google Classroom to get responses from participants. We are very happy and happy, because their response to this training is very good as evidenced by the practice of the knowledge and skills we provide.

\section{CONCLUSIONS AND RECOMMENDATIONS}

The conclusion of this community service program is the implementation of service activities in the form of training that is in accordance with the needs of partners. There is a training module that can be used by educators and education staff. The teachers and staff who participated in this activity were quite enthusiastic and completed the given exercises. The service team also controls the results of the participants' training in Google Classroom.

Suggestions for the goodness of the next service program is to provide more time. After the training, on different days, it is programmed for advanced technical guidance, so that if there is something you want to discuss, it can be facilitated.

\section{ACKNOWLEDGMENTS}

Thanks to 1) LPPMP Bhayangkara University, Greater Jakarta, 2) Headmaster of SDN Hurip Jaya 03 Babelan, 3) Training participants, and 4) Community service team.

\section{REFERENCES}

Adisel, \& Prananosa, A. G. (2020). Penggunaan Teknologi Informasi dan Komunikasi dalam Sistem Manajemen Pembelajaran pada Masa Pandemi Covid 19. Journal of Administrasi and Educational Management, 3(1), 1-10.

Aisa, A., \& Lisvita, L. (2020). Penggunaan Teknologi Informasi dalam Pembelajaran Online Masa Covid. Journal of Educational and Management Studies, 3(4), 47-52.

Astini, N. K. S. (2020). Pemanfaatan Teknologi Informasi dalam Pembelajaran Tingkat Sekolah Dasar pada Masa Pandemi Covid-19. Jurnal Lampuhyang, 11(2), 13-25.

Kasmawati. (2020). Pemanfaatan Aplikasi Google Form dalam Pelaksanaan Supervisi Akademik di Masa Pandemi Covid-19 pada Sekolah Binaan di Kabupaten Takalar. Jurnal Sipatokkong BPSDM Sulawesi Selatan, 1(2), 137-142. http://ojs.bpsdmsulsel.id/index.php/sipatokkong/article/view/28/15

Manullang, S., Siregar, N., \& Sitompul, P. (2021). Pelatihan Google ClassRoom untuk Guru-Guru SMP Satu Atap Patumbak. Jurnal Pengabdian Kepada Masyarakat2, 27(2), 186-191.

Muafani. (2021). Pemanfaatan Teknologi Informasi Di Tengah Pandemi Covid-19 dalam Pemberdayaan Masyarakat. Jurnal Penelitian Dan Pengabdian Kepada Masyarakat, 8(2), 134-139. 
Priatna, W., \& Purnono, R. (2020). Implementasi Fuzzy Inference System Metode Sugeno Pada Aplikasi Penilaian Kinerja Dosen. Techno.COM, 19(3), 245-261. https://doi.org/10.33633/tc.v19i3.3638

Purnomo, R., \& Putra, T. D. (2020). Pemberdayaan Sumber Daya Desa Sukawijaya melalui Teknologi Informasi. Jurnal Sains Teknologi Dalam Pemberdayaan Masyarakat, 1(1), 33-38. https://doi.org/10.31599/jstpm.v1i1.60

Ramadhani, F., \& Arifin, Y. (2013). Optimalisasi Pemanfaatan Teknologi Informasi Komunikasi Berbasis E-Commerce Sebagai Media Pemasaran Usaha Kecil Menengah Guna Meningkatkan Daya Saing Dalam Menghadapi Masyarakat Ekonomi Asean 2015. Economics Development Analysis Journal, 2(2), 135-139. https://doi.org/10.15294/edaj.v2i2.1401

Romadani, A. T. F., \& Prasetyo, D. (2020). Pemanfaatan Teknologi Informasi dan Komunikasi dalam Mata Kuliah Bahasa Indonesia di Perguruan Tinggi. Jurnal Edukasi Khatulistiwa, 3(2), 54-61. https://doi.org/10.26418/ekha.v3i2.42311

Zulfahmi, Mamase, A. R. Y., \& Pratiwi, W. (2020). Pemanfaatan E-Commerce Dan Pemahaman UU ITE Untuk Meningkatkan Kompetensi Siswa Smkn 1 Pontianak. Jurnal PKM Prodi Manajemen, 1(2), 7-15. 


\section{APPENDIX}

Tabel 1. Details of training activities

\begin{tabular}{|c|c|c|c|}
\hline NO & WAKTU & KEGIATAN & PENGISI \\
\hline 1 & $08.00-09.00$ & $\begin{array}{l}\text { Peserta mengisi daftar hadir. } \\
\text { Peserta di periksa suhu tubuh } \\
\text { dengan ThermoGun }\end{array}$ & Panitia Sekolah \\
\hline 2 & $09.00-09.10$ & Pembukaan dan Doa Pembuka & MC \\
\hline 3 & $09.10-09.20$ & Menyanyikan lagi Indonesia Raya & MC \\
\hline 4 & $09.20-09.30$ & Sambutan Pengawas Sekolah & Bpk. H. Moch. Makmur \\
\hline 5 & $09.30-09.40$ & $\begin{array}{l}\text { Sambutan Kepala SDN Hurip Jaya } \\
03\end{array}$ & $\begin{array}{l}\text { Ibu Isti Butsiawati } \\
\text { Susanto, S.Pd. }\end{array}$ \\
\hline 6 & $09.40-09.50$ & $\begin{array}{l}\text { Sambutan Perwakilan Ubhara } \\
\text { Jaya }\end{array}$ & $\begin{array}{l}\text { Bpk Rakhmat Purnomo, } \\
\text { S.Pd., S.Kom., M.Kom }\end{array}$ \\
\hline 7 & $09.50-10.00$ & Pengisian Pre-Tes & $\mathrm{MC}$ \\
\hline 8 & $10.00-10.30$ & $\begin{array}{l}\text { Materi (1) Mengenal, } \\
\text { Mengkonfigurasi, dan } \\
\text { menginstalasi Modem WiFi dan } \\
\text { USB WiFi \& Diskusi }\end{array}$ & $\begin{array}{l}\text { Bpk Rakhmat Purnomo, } \\
\text { S.Pd., S.Kom., M.Kom }\end{array}$ \\
\hline 9 & 10.30011 .15 & $\begin{array}{l}\text { Materi (2) Presentasi tentang Bijak } \\
\text { Menggunakan Internet \& Diskusi }\end{array}$ & $\begin{array}{l}\text { Wowon Priatna, S.T., } \\
\text { M.TI. }\end{array}$ \\
\hline 10 & $11.15-12.00$ & $\begin{array}{l}\text { Materi (3) Mengetik cepat dengan } \\
\text { metode } 10 \text { Jari \& Diskusi }\end{array}$ & $\begin{array}{l}\text { Bpk Rakhmat Purnomo, } \\
\text { S.Pd., S.Kom., M.Kom }\end{array}$ \\
\hline 11 & $12.00-13.00$ & ISHOMA & \\
\hline 12 & $13.00-14.20$ & $\begin{array}{l}\text { Materi (4) Penggunaan google } \\
\text { form, google classroom, dan } \\
\text { aplikasi shorter URL \& Diskusi }\end{array}$ & $\begin{array}{l}\text { Wowon Priatna, S.T., } \\
\text { M.TI. }\end{array}$ \\
\hline 13 & $14.20-14.30$ & Pengisian Post-Tes & MC \\
\hline 14 & $14.30-14.40$ & Menyenyikan lagu Bagimu Negeri & $\mathrm{MC}$ \\
\hline 15 & $14.40-14.50$ & Kesan - Pesan Peserta & MC \\
\hline 16 & $14.50-15.00$ & Doa Penutup & MC \\
\hline
\end{tabular}
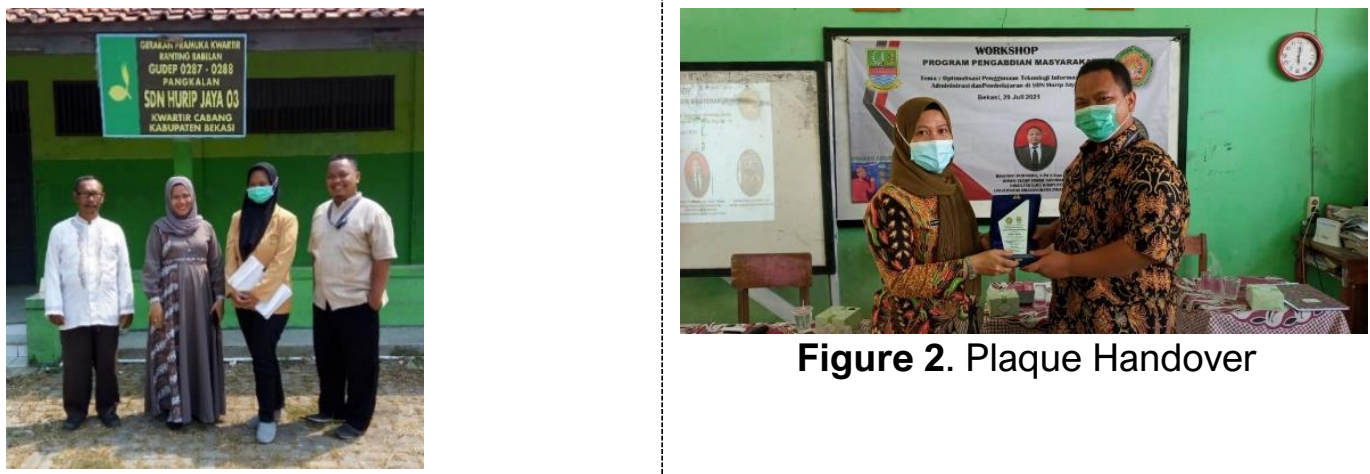

Figure 2. Plaque Handover

Figure 1. Observation Activities 


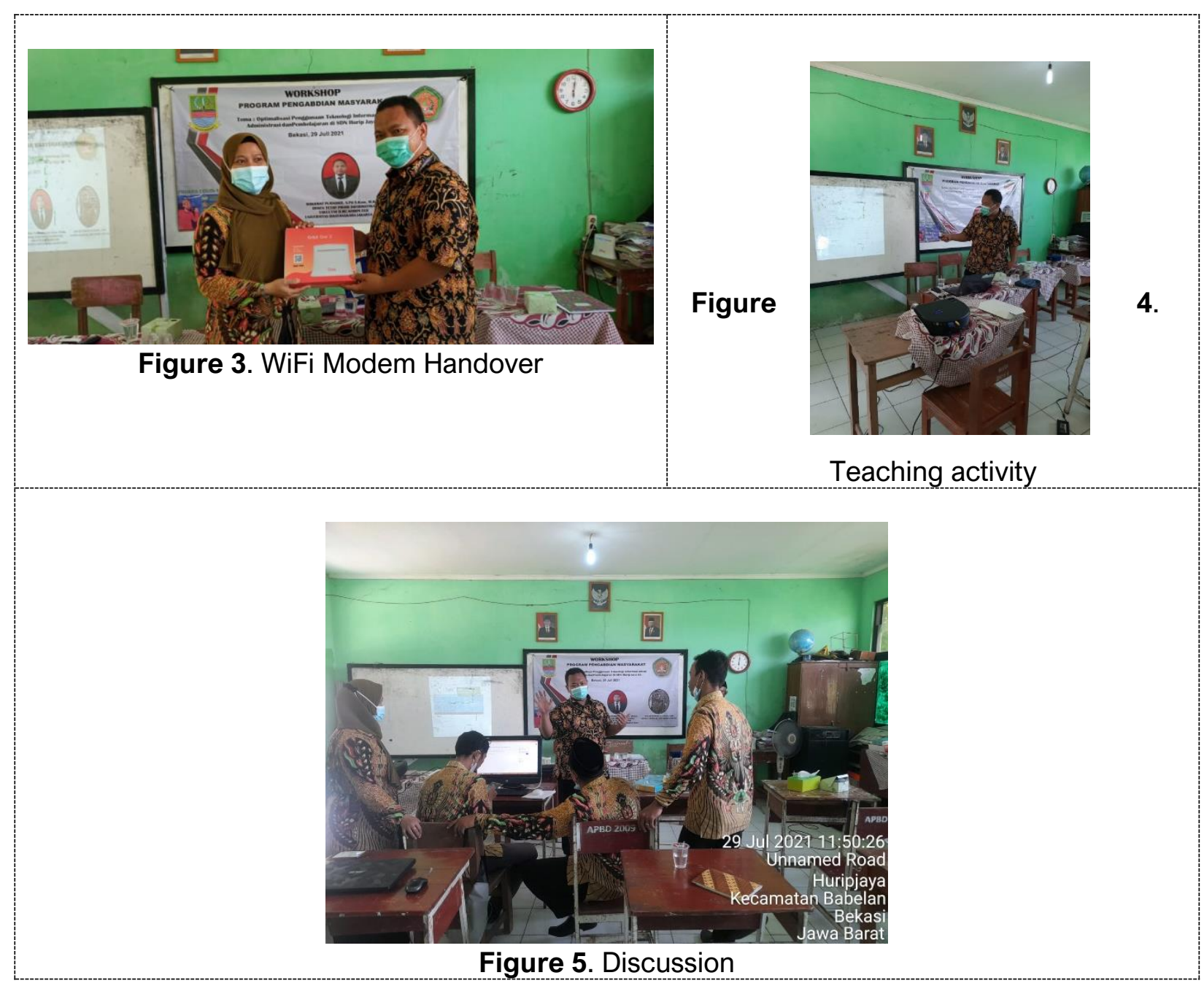

